\title{
Politics, Music and Social Mobilization in Africa: The Nigeria Narrative and Extant Tendencies
}

\author{
Okeke, Remi Chukwudi \\ Department of Public Administration and Local Government \\ University of Nigeria, Nsukka \\ remiokeke@gmail.com
}

\begin{abstract}
Keywords: Elite Theory, Political Economy, Political Elite, Fela Anikulapo-Kuti, Colonialism, Political Mobilization, Youth Population
\end{abstract}

\begin{abstract}
The impact of music on politics in Africa has seemingly remained dominant. But the overall sway of the African political processes has also become bewildering. The panacea to the disconcerting results of these political procedures in Africa is the adequate levels of social mobilization, while music ostensibly mobilizes massively. This paper thus examines the linkages among politics, music and social mobilization in Nigeria (the most populous African country). Framed on the supposition that the relationship among politics, music and social mobilization in Nigeria (Africa) is now downbeat and using the elite theoretical and the political economy frameworks of analyses, the author studies the intervening factors responsible for the observed gloom in what had amounted to progressive relationships among politics, music and social mobilization in Nigeria and the wider continent. The research setting is qualitative. The work delves into its premises through logical argumentation.
\end{abstract}

\section{Introduction}

Music had impacted profoundly on politics and social mobilization in Africa. Political communication was accordingly very much facilitated by music on the continent. The Nigerian space was not immune to these musical impacts. From the pre-colonial, colonial to the post-colonial periods in the country therefore, the mechanism of music was in a net-position, effectively deployed in social mobilization and political communication. But something else seems to have intervened in the hitherto positive relationship among politics, music and social mobilization on the continent, particularly in the Nigerian nation. These intervening variables are researched in this paper as the incidences of elite avarice and a disarticulated political economy. Consequently, the paper is framed on both the elite theory and the political economy paradigm of social science investigation. The political elite are under this setting studied as distortive agents, while the political economy is perceived as the milieu of exchanges between the political and economic tendencies in a state. It is conceded however, that in social science scholarship, the political economy conceptualization still necessitates other variations.

The work thus studies the effect of the political economy on the relationships among politics, music and social mobilization. The elite factor (deriving from the elite theory) is central to the relevant interrogations. The music divergence of the study and the historical antecedents of the expositions, invariably give an immense multidisciplinary coloration to this contribution but does not make the paper fundamentally attributable to the music discipline. Then the question may still arise: Why making a Nigerian-specific contribution, within a wider African context? Several scholars have on this score aptly argued that the ways of the Nigerian state symbolize fundamentally the general African debilitating tendencies (Adebanwi \& Obadare, 2010; Sen, 2010; Smith, 2010; Kashim, Ogunduyile \& Adelabu, 2011, Kinnan, Gordon, DeLong, Jaquish \& McAllum, 2011; Amao \& Maiangwa, 2017).

Nigeria is the most populous country in Africa, and will have nearly 250 million people in about a decade from the current date (Kinnan et al., 2011, p. vii). The country is also an important regional force on the continent, stemming principally from her size, but additionally because of some leading political and economic roles it had played in the past. Besides being one of the largest 
economies in the African region, Nigeria is among the world's major producers of crude oil. Furthermore, Nigerian leaders have mediated in major conflicts in Africa, while troops from the country have played leading roles in the quest for peace and stability in the world (Amao \& OkekeUzodike, 2015, p.1). The common threads among these viewpoints on the position of the Nigerian state in African (global) affairs, suggest that in the broad African interest, the continuing problem of unhelpful policy postures in Nigeria should be solved urgently.

The earlier contributors to the subject of Nigeria in African / world affairs are in agreement that the obstructive cultural peculiarities of Nigeria, indeed, create immense impediments to the undisputable recognition of the African voice on the global arena. The Nigerian political elite have for instance, stolen nearly all the resources the discovery and exploitation of oil attracted to their country, between 1958 and the current period. Politics in the Nigerian nation has accordingly remained historically an elite-masterminded phenomenon. While more than half of the Nigerian population still grapples with extreme poverty therefore, a small group of the nation's elites enjoys ever-growing wealth (Oxfam International, 2017, p.4).

Political power in Nigeria has thus become inverted, belonging largely to the elite as opposed to belonging to the people (Emecheta, 2016). Election rigging is the central mechanism of gaining access to power in the country (Agbaje \& Adejumobi, 2006; Awopeju, 2011). The other complementary vice (the corresponding crime) is electoral violence, which continues to defy all ostensible policy measures put in place to check it (Onah, 2009; Ikpe, 2015; Ashindorbe, 2018). Consequently, the Nigerian narrative features gargantuan inequalities (Bakare, 2012; Umukoro, 2014; Ogbeide \& Agu, 2015; Oxfam International, 2017). The country's story thus typifies a tale of contradictory underdevelopment, whereby a few of the citizens are immensely rich while most of their compatriots are abjectly poor. Bakare (2012, p.52) further opines that any country where the distribution of income is heavily concentrated in the hands of the few is an epitome of underdevelopment and poor economic management. And the Nigerian situation is invariably a chronicle of poor economic decisions.

Hence, Nigeria is a clear example of a country at risk of failure, with an ensuing major global impact. And while each African nation is important, none likely has more than Nigeria, the potential to dramatically alter the strategic environment on a universal scale (Kinnan at al., 2011, p. 2-3). Solving the embedded Nigerian problems would accordingly translate into the creation of a definitely result-oriented roadmap for African progress and development. Thus, Nigeria is an alluring research challenge.

The general objective of this essay therefore is to examine the issue of politics, music and social mobilization in Nigeria and ultimately undertake an analysis of the current tendencies. The contribution is significant in both theoretical and empirical dimensions. In the first place, its interdisciplinary aspirations present a benchmark for further research-efforts in the area of the generic nexus between politics, music and social mobilization. And in empirical terms, democracy in the Nigerian nation has to all appearances remained practiced on the basis of trial and error. This work therefore is an effort in the regards of building the processes of politics (democracy) in the Nigerian nation and invariably in Africa, by highlighting the features of the glorious past, and accordingly, making forecasts on a splendid future for politics and democracy in this specific country and on the wider continent. The research effort remains framed on the elite theoretical template and the political economy paradigm of scholarship, within an overall context of multidisciplinary contribution.

\section{Conceptual Elucidation: Social Mobilization}

Social mobilization is highly unwieldy to conceptualize and seemingly an everyday terminology, definable by nearly everyone. To the politician, the musician, community health activist, human rights advocate and so forth, therefore, social mobilization is an imperative of their diverse engagements. And even to the revolutionary, social mobilization is a requirement of purposeful activism. But what does social mobilization truly stand for? What does it generically represent? According to Unicef (2017) therefore, social mobilization is that process of engaging a wide range of traditional, community, civil society and opinion leaders around a common purpose, as it reaches out to non- 
governmental organizations, professional groups/networks, youth groups, women's groups, community-based organizations, faith-based organizations, professional networks and the private sector, to catalyze these different groups to action and/or support change as a common cause.

Cardoso, Lapa \& Fátima (2016, p.3910) define social mobilization as one particular dimension of political participation, outside the institutional and regular political participation, by voting and militancy, relying on the autonomy of individuals. But this definition is extremely contentious. It particularly subsumes social mobilization into political participation (not even political mobilization). Tufte in Sam (2015) highlights that social mobilization is not a new phenomenon, as it has existed since the 19th century, under the broad nomenclature of "civil rights movements" in the USA, Latin America and some African countries. The fundamental tenets of these movements, Sam (2015) posits, were aimed at claiming a space and articulating voice and citizens' role in the development of their societies. Dunu \& Uzochukwu (2015, p.12) then assert that social mobilization could be defined simply as a means of inspiring people to active action and engagement, concerning social issues, as the key for mobilization is to inspire and motivate individuals, to go from the comfort of their homes to engage in development actions.

For Deutsch, (1961, p.493), social mobilization refers to a generic process of change, which occurs to significant parts of the population in nations which are transiting from traditional to new ways of life. He suggests therefore that social mobilization is a peculiarity of needy nations, grappling with the challenges of modernization. The linkages that Deutsch attempts to establish between social mobilization and the transformation of political behavior / its relevance for politics are however, critical to the purposes of this study. The positions of Adamolekun (1989) also agree with the perspectives of Deutsch (1961) in spiritedly attempting to establish linkages between social mobilization and the imperatives of national development.

Nsude \& Isika (2016, p.74) further add that mobilization involves using good communication strategies in appealing to people in a convincing manner, to adopt particular patterns of desirable behavior. It consequently implies getting together for service and has to do with achieving a goal, through a properly articulated group action (Nsude \& Isika, 2016, p.74). Social mobilization is accordingly, a comprehensive approach to the unification of the people of a given community in pursuit of common goals. In social mobilization therefore, the boundaries of sex, religion, gender, color, class, race, ethnicity and related classifications are completely disregarded. The essential purpose of social mobilization is indeed, the unification of a people, under a common agenda.

What is the relationship between political mobilization and social mobilization? Political mobilization is (in this work) a sub-set of social mobilization. Its effective type is targeted at only the germane members of a community. For instance, it would be defective or even futile to "politically mobilize" the citizens of non-voting age in a state (at the time of general elections). Such juvenile denizens may although, attend political rallies, even as miscreants in politically volatile environments. They may even illegitimately engage in social media exchange of political abuses. But the processes that lead to their dispensable presences are not profoundly describable as political mobilization, which refers essentially to the process of engaging and sustaining the interests of the relevant citizens of a state in political affairs. These pertinent nationals may be registered voters or even their counterparts of voting age who are not yet registered for such purposes.

Furthermore, political mobilization may entail the encouraging of adult citizens to enlist as members of subsisting political parties in a given nation-state. It may suggest also the process of legitimately engaging the interests of sundry organizations and corporate bodies of a state in political matters. Then from a revolutionary perspective, Evans (2007, p.40-41) suggests that the objective of political mobilization is to transform the masses into an unstoppable weapon, as it corrects the problem of a neutral population, pushing the masses from a state of neutrality to a state of revolution.

But revolution in this study only refers to the replacement of a historically avaricious political class in a polity by some more temperate leaders. It does not suggest the overthrow of a government. And it does not also indicate a tendency towards being enamored by violence. Political mobilization is accordingly, highly prone to partisan and contentious considerations. Evans (2007) has in these regards added a combative and controversial trajectory to the specific conceptualization of political 
mobilization, by broaching revolution. According to Duvall \& Welfling (1973, p. 675) therefore, social mobilization has been related to political conflicts in various (and often contradictory ways). Hence, while much of early literature viewed social mobilization as a prerequisite to political "development", it is also possible for social mobilization to lead to political "disintegration".

Thus, relative to the declines in South Africa's evolving political culture and the country's African National Congress (ANC), Reddy (2010, p.185) refers to what he calls the increased social mobilization of disgruntled citizens, who rely on a discourse of violence, rather than articulating grievances, through political structures. The incidence of mobilizing disgruntled citizens is underscored in this instance, suggesting that both dissatisfied (disgruntled) and contented nationals are subject to mobilization. Political and social mobilizations are accordingly interrelated. But despite the linkages, social mobilization is more all-embracing in its nuances and the conceptual intentions are less disputative. As a critical variable of this paper therefore, social mobilization is devoid of any inaccuracies. It is deliberately a part of the study's research focus. Thus, fundamentally in the study, social mobilization is the compelling galvanization of the masses, into undeviating patriotism. It is the process of enlisting the services of most citizens in matters of the state.

\section{Politics, Music And Social Mobilization in Africa: Selected}

\section{Historical Narratives}

In pre-colonial Africa, music preceded or accompanied the arrival of leaders to certain assemblies of the people. Such occasions included crucial political gatherings, particularly when one community was about to engage another in competitive exchanges. The arrival of each leader and eventually, the entry of the numero uno, were marked by musical exhibitions. The exit of the number one leader at such gatherings (signifying the end of the forum) was also marked by musical demonstrations. Furthermore, in the pre-colonial, the anti-colonial and post-independence eras, the music that was associated with leaders, which depicted their presence and exit at political gatherings, was selfevidently communicative. Such music attempted and indeed usually (re)connected the leader with his or others' previous heroic exploits and animated him (even inebriated him) for present purposes.

Then under colonialism, the preceding chronicle was naturally affected by a setback, as the colonialists either did not understand or deliberately failed to understand that music could also be indigenous to their African subjects. Everything the natives displayed in form of music was seen by the colonial master and his missionary contemporaries as weird and condemnable paganism (even voodooism). In the specific case of masquerade parades, and their music accompaniments, it was additionally terrifying to the colonizer. But it was not only music that encountered demobilization under these colonial contexts; the very question of politics was practically anathema. Social mobilization was consequently subdued, except for the colonial masters' mercenary purposes.

Invariably, whatever that logically facilitated the process of colonialism could be anything but social mobilization. However, the mortifying scenarios of even denying the subjects the rights to play and enjoy their music did not last for too long. The subjugated people were soon constantly caught on the wrong side of the invaders' laws and were accordingly thrown into various prisons. But as prisoners, it was no longer possible to prevent them from creating and playing some form of music. And so re-enters music as a form of mobilization, both in the ordinary social and more so, in the political contexts.

This period in our narratives also synchronizes with the period of anti-colonial struggle. Modern musical compositions could now be made in praise of the leaders of the anti-colonial movements. On the other hand, the resistance activists also learnt to use dance and music for recreation, entertainment and creativity. The white man's tastes and tendencies in music had also at this time become attractive to the African nationalists. The ballroom dance accordingly became fashionable among the colonizer and the colonized. Nationalism after all could do with some tinges of dancehall exuberance, as all work without play may dull the mind and lead to an anticlimax in the resistance to colonial occupation. Politics, music and social mobilization at this time consequently found some common grounds in the African and Nigerian settings. 
Under the postcolonial situation, it was a slightly different relationship among the variables of politics, music and social mobilization in Nigeria. There were politics and music as in the previous period(s) but the element of social mobilization had commenced the singing of divergent songs. The greed of the elite had replaced the generic spirit of nationalism which was prevalent in the preceding period. The ballroom dancing of the previous era continued, but only for the imprudence of the covetous postcolonial elite. There actually became a chasm between the music of the new masters (metaphorically and otherwise) and the tunes the masses waited to receive. There also emerged at this point, the warlike character of politics that created different versions of the elite camp. And the orthodoxy became the composition of competitive music in eulogy of the kingpins of the political macabre dances that emerged. In an overall context however, music at this point was utilized in political communication. But its efficacy in social mobilization was contentious, as it woefully failed in healing the wounds of divisiveness in the Nigerian polity in specificity and in the larger African context.

But traditional African societies were essentially built on social mobilization. They were nonatomistic and highly organic communities. Mijuskovic (1992, p.147) maintains that while the organic paradigm stresses the ideal unity of the whole, the atomistic construction emphasizes the value of individual freedom. Mengisteab (2006, p.3), further highlights that in large parts of Africa, the precolonial political systems were highly decentralized. The ideal unity of the whole (Mijuskovic, 1992, p.147) actually alludes to the tenets of social mobilization. And even where wars were fought by these traditional societies, the belligerent efforts were foreshadowed and executed on the platforms of social mobilization.

It was subsequently the incidence of colonialism which brought about the mollification that endangered social immobilization in Africa. Colonialism entailed defeat and subjugation. And it also meant a large degree of incapacitation. Then as the colonial tendencies unfolded, it equally implied a certain tolerance of some worldviews of the colonizer, and in these regards hidden (in some instances, even overt) admiration of specific cultural hues of the colonial invaders. The colonialists were master strategists, even in the dubious regards. They knew that to completely subdue a people, the potentially fruitful schemes would include, striking at all the people's cultural platforms. The successful lines of attack would also entail the dismembering of all such social particularities of the people. This was what the colonial intruders did in Africa.

Without a people's culture, they are thoroughly emasculated. Societies are largely made lively and great by the potency of their cultures. Communities of people are given essence by their cultural prides and indestructible antecedents. Culture thus informs and innervates social mobilization. By undermining the African cultural roots therefore, colonialism in a way placed social mobilization on hold in the continent. Africa was accordingly conquered by colonialism. And it was the inauspicious time for social mobilization as it was previously known by the African aborigines. The postcolonial era therefore led ideally to what Boone in Englebert (2002, p.51) would describe as new forms of social mobilization.

\section{The Specific Music Dimension to Social Mobilization in (Ancient) Africa}

Ojukwu, Obielozie \& Esimone (2016, p. 114) highlight that the ancient African societies did not demarcate their daily activities from their music. Hence, most music performances in the continent went beyond the borders of mere entertainment but were greatly geared towards socio-cultural features due to the ability of music to socialize, consolidate values and other utilitarian exigencies. This is still the current thesis in the music-society nexus in Africa. Fayoyin \& Nieuwoudt (2017, p.1) thus posit that the power of music to move, can be particularized, but also has a shared nature. Omojola in Adeoye (2013, p.10) suggests that in many ways, traditional African music is rich in historical and philosophical issues, bringing about communal binding, social values, warning erring members of the society, praising people to whom honor is due, recalling of the achievements of the leaders, as well as reinforcing the legitimacy of present ones.

Akpabot in Adeoye (2013, p.11) notes that songs of social control in Africa were (are) usually topical and appropriate to a given community; they are either of praise or abuse, designed to regulate the social order. Akpabot highlights that sometimes, such songs are philosophical and humorous, 
since the African's sense of humor is best expressed in songs and proverbs. Then in the specific case of pre-colonial Nigeria, music differed in style, theme, and lyrics, according to the practices in each ethnic group (Adebayo, 2017, p.59). Nigerian musicians also played active roles in the quest for the attainment of the country's independence. And even after independence in 1960, the local musicians were in the forefront of calls for social justice and political transformation (Adebayo, 2017, p.61).

Music's immense influence was furthermore, evident in the struggle for independence in most African countries, as rallies, protests, and movements were laced with music and dances; musicians released albums that were filled with contents, calling for the emancipation of their different countries (Adebayo, 2017, p.61). Akpabot in Adeoye (2013, p.11) further posits that all the recognizable categories of song texts in African music are easily classifiable as (a) praise songs (b) songs of insult, and (c) songs for entertainment. And out of all these classifications, songs of praise are commonly used to praise good leaders and good deeds in the society, while the songs of insult are used to condemn the unwholesome behavior of people in the society. Music therefore plays pivotal role in social mobilization in contemporary Africa, still reflecting the cultural antecedents of ancient times.

There was still in primordial Africa, the role of the oral bard, who used songs, drums and poetry to comment on social and political events (Adegoju, 2009, p.21). There were truly immense musical contributions to social mobilization in the traditional African society. Traditional festivals were / are important platforms for social mobilization in Africa (Abioye, 2017, p.102). And in both the ancient and modern Africa, music remains an integral part of these festivals.

\section{Politics and Music in Nigeria: Additional Narratives}

Fayoyin \& Nieuwoudt (2017, p.2) posit that indications from political and social perspectives have shown the role of music in the society as a means to persuade, control or advance social causes. Hence, while essentialists and poets may depict music as a universal language and part of humanity's code of chronicles, music has also been instrumentalized and harnessed as a tool of social mobilization. Consequently, Nigerian musicians like Fela Anikulapo-Kuti, Sony Okosun, Onyeka Onwenu, Christie Essien Igbokwe, Dan Maraya Jos, Femi Kuti, Bisade Ologunde (Lagbaja), have severally used their music to mobilize the populace towards social change (Adebayo, 2017, p.62). The list of socially conscientious Nigerian musicians (of contemporary era) may still include Eedris Abdulkareem, who in his album, Mr Lecturer titles one track, Nigeria Jagajaga, referring to the state of disorderliness in the country, and Chinagorom Onuoha, also known as African China, who in his album titled Crisis, labels the Nigerian government as 'bad' for their perceived insensitivity to the plight of the ordinary people (Adegoju, 2009, p.5).

In his second album, titled $M r$ President, African China expressed profoundly, his disenchantment with the lack of basic social amenities in Nigeria. The major subject of Adegoju's work was of course, Bisade Ologunde, popularly called Lagbaja, whom he describes as an artist submerged in meaningful mystery (Adegoju, 2009, p.2-7; Okuyade, 2011). The Nigerian musician named Blackface also released his Hardlife album, which focused on the generic downside of life in the country. Additionally, Sound Sultan, with his Ole, a Yoruba word for thief, sang in condemnation of bad governance in the Nigerian nation (Barclays, 2014, p.7). Adviser Nowamagbe, who may sound nationally unfamiliar in the Nigerian music industry but well-liked in the Edo State of the country, belongs to this list of socially conscious Nigerian musicians. Nowamagbe, an apostle of the legendary Fela Anikulapo Kuti, indeed appears to be doing with his Highlife-Afro brand of music, what the later did in the realm of social mobilization in Nigeria (Barclays, 2014, p.9-15). But generally in the history of the Nigerian nation, the role of the late Fela Anikulapo-Kuti, in using music as an instrument of social mobilization remains legendary and matchless.

But in spite of the above expositions, politics has continued to take a superior position to music in the country. The nation's generic political elite, whose immense influence arises from their seemingly limitless access to the national economic resources, have continued to appear larger in importance than the national musical icons. Hence, Osiebe (2015) demonstrates that an increased number of popular musicians in the country started producing protest and unity political music, following Nigeria's new wave of democratization in 1999, principally as a way of alerting audiences of their political astuteness, and in an attempt also to court political relevance. 


\section{The Extant Tendencies and the Effects on Social Mobilization}

Radio jingles and musical videos (relayed on television) and recorded songs heard through the loudspeakers (fixed to the rooftops of campaign vans) have been some of the methodologies of the continuing relationship between politics and music in Nigeria. Recently also, the social media became an important part of the avenues of this politics-music linkages (Ijeh, 2012; Titus \& Bello, 2012; Olatunji, 2013; Amifor, 2015; Ademilokun \& Olateju, 2016; Ofulue, 2016; Nwosu, 2017; Salaudeen \& Adebiyi, 2017). Olatunji (2013, p.256) demonstrates that currently in Nigeria, the use of talking drums during political campaigns in several communities, is common and often, this turns political campaign locations into carnivals, as musical artists entertain potential voters and others, during such rallies. The competing political parties similarly engage the services of praise singers and local drummers to eulogize their candidates.

There was likewise recently in the 2015 elections in Nigeria, an obvious attempt to link music and the new media in political communication. Social media is embraced for a number of reasons in the country, inclusive of political mobilization. The most well-liked pages on Facebook in the country include highly admired Nigerian musicians, P-Square and Young Paperboyz. The most popular Twitter accounts on the other hand almost entirely belong to Nigerian musicians and music producers (Bartlett, Krasodomski-Jones, Fisher \& Jesperson, 2015, p.11). This study thus begins to arrive at a component concept of youth's concerns, as social mobilization is not an end in itself. It specifically entails the mobilization of the youths of a nation-state for national development.

Consequently, music for electoral gain must focus on the youths and their musical attractions, which can only be successfully built on the assumption that the targeted population of the young ones is a plausible electoral asset, devoid of voter apathy. MINDS (2016, p.2) thus highlights in the overall African context of the study, that young people were very frustrated with how the African continent was performing. Frustrated by lack of economic opportunities, the young people had lost faith in political structures and processes. And they have also lost faith in the electoral processes in particular (MINDS, 2016, p.2). Such youths may therefore fully dance to the music of their beloved artists at political gatherings, but the dance may not translate to electoral profits for the political parties at the end of the day. Asaju, Arome \& Anyio (2014, p.12) highlight that the incidence of unemployment in Nigeria in the 21st century is alarming. And the Nigerian unemployed persons are mainly from the youth segment of the population. These youths are the people for which the musicians contradictorily play at the political rallies (negating the need for social mobilization).

This work further draws an analogy from the Caribbean island of Jamaica and the nation's reggae-rich narratives. Reggae from its lowly-natured origins in the country eventually grew into a fundamentally protest and politically relevant music. This brand of music was ultimately invented by socially conscious citizens (with latent creative powers), and finally led to successful political interventions and activisms in the country. Chang \& Chen (1998, p. 53) thus posit that politics, music and culture are inextricably intertwined in Jamaica. But it is a different setting in the Nigerian state. There are therefore currently in Nigeria, no compelling linkages among politics, music and culture. This further crystallizes into negative linkages among these variables and social mobilization.

The attempts to infuse music into political rallies, for purposes of vote-seeking in the country therefore serve little or no political communication (social mobilization) purposes. The performing musicians are undeniably the types the Nigerian youths adore and so the young men and women attend such gatherings to see their favourite artists on the platform. But the outcome of Nigerian elections is usually influenced by greedy political elites who may not truly be followers of the reigning musicians. Above all, there have been no self-evidently fruitful policies and progammes (in general terms) addressing the challenges and needs of the country's youths. Watching their favourite musicians entertain at political rallies thus ranks among the least of the worries of a highly marginalized national youth population. The musicians accordingly neither play for the youths nor the elderly at these events. Their famed performances in other words, hardly count in vote garnering realities. 
According to Gyimah-Brempong \& Kimenyi (2013, p.21) there is generally in Africa, a lack of comprehensive youth policies, integrated with national development plans and broad macroeconomic policies. And there is also a general lack of adequate human and financial resources devoted to youth issues, which has resulted to the creation of youth's ministries that exist but have very little functionality. The Nigerian nation is not immune to this general trend and its associated failings. Furthermore on the revolutionary trajectories of the study (revolution still stands for fundamental change in the work), Evans (2007, p.44) opines that the people will not automatically gravitate to the generic and germane political goal of society. They have to be slowly and patiently educated in the critical political goal before they will join the revolution (before they will join in actualizing the purposeful goals of society). Music does become instrumental, in this slow and patient task of education and social mobilization.

Music is undoubtedly a potent method of communication, perhaps more powerful than the soapbox deceptions of the Nigerian political elite. Sobowale (2013) highlights the criticality of effective communication in the matrixes of imperatives for purposeful representation by the Nigerian politician. He posits however that the Nigerian political elite remain pathologically deficient in effectively deploying communicative tools (for instance, music) in the service of the citizenry. Titus \& Bello (2012, p.172) also contend that campaign songs should disseminate the candidate. The Nigerian campaign songs however, are mere exercises in the culture of "share the money" whereby the political elite merely extends their ignoble largesse, arising from stolen public funds to the musicians. Barclays $(2014$, p.1) thus argues that in an era where pop music has taken over the entertainment scene in Nigeria, and indeed the world, one thing that is worrisome is that most of the lyrics of songs have little or nothing to offer society, in the sense that they are just 'all sound and no message' for listeners. These songs (in other words) do not serve the purposes of social mobilization.

Wader, Jumare \& Imam (2016) argue that the role music and musicians played during the Nigerian election of 2015 was significant in the change of government which ensued. They identified these Nigerian musicians: Olamide, Aminu Ala and Dauda Kahutu Rarara, as some of the local artists who gave the All Progressive Congress (APC), the strategic support and alliance which facilitated the party's victory against the incumbent People's Democratic Party (PDP). (The success of the APC against PDP was at the central and some state levels in the country). But what was the generic impact of such politico-musical coalition? The partner-musicians were indeed merely looking for their daily bread. The musical relationship was not actually in the spirit of nation-saving social mobilization. The political source had become a dominant economic means in the country, owing to the antics of mendacious political elites.

Adeoye (2013, p.9) argues that music is a way of life which carries the attributes and values of the culture it represents, and it is a preserver, promoter and transmitting agent of facts, values, norms and various cultural practices of any given society (from one generation to another). In other words, music is an instrument of social mobilization. But the musical compositions and displays of sound and no message (Barclays, 2014, p.1) can hardly serve the purposes of social mobilization. Then using a broad theme of celebrities / entertainers (under which many Nigerian musicians are classifiable, even for the purposes of this paper), Itiri (2015) examines the nature of the influence the musical artists brought to bear on the 2015 electoral contest in Nigeria. Invariably, the substance of the numerous artists' participation is economic. The ravenous political elite in the country needed to exploit the opportunity of the entertainers' popularities by offering part of the illicit funds, stolen from the public treasury (by the politicians) to the musicians. The entertainers also obviously required the additional financial resources, in an era of economic uncertainties (created of course by the untrustworthy political gladiators in the country). Social mobilization was largely ruled out of these considerations and political equations. 


\section{The Economy and the Political Elite: Summative Linkages}

A critical quality of music is in its intrinsic coloration. However, under the discordant realities of the Nigerian economy, music has become immensely imbued with emergency factors, in place of its core values. Under this scenario, music becomes a practical alternative to unemployment for many of the nation's youths. The Nigerian unemployment situation is of high immensity (Akeju \& Olanipekun, 2014; Asaju, Arome \& Anyio, 2014; Yelwa, David \& Awe, 2015; Tule, Oduh, Chiemeke \& Ndukwe, 2018). In the specific case of youth unemployment, the country is certainly at a huge crisis point (Oyelola, Igwe, Ajiboshin \& Peluola, 2014; Akanni \& Adam, 2017; Dike \& Dike, 2017; Musa, Abdullahi \& Baba, 2017). Curiously however, the contents of music from the defiant youths are not culturally deep. But they successfully mimic foreign tastes and consequently attract foreign / domestic patronages. Popular music thus becomes an economic tool for Nigerian youths (Babalola, 2014). And also a political tool for the political elite

Consequently, the Nigerian contemporary pop music is playing an increasingly pivotal role in shaping the African continent's music scene (Ojukwu et al., 2016, p. 114). The works of the youths thus become classifiable as commercial successes but these same efforts continue to fail on the Nigerian home front in the critical regards of social mobilization. Ojukwu et al., (2016, p. 120) further posit that Nigeria's popular music industry is unarguably one of the most diverse in the world. According to Barclays (2014, p.6) the songs are popular in dancehalls and may be winning awards, here are there, but they hardly make any sense to listeners. Onikoyi in Barclays (2014, p.6) then adds that with the current Nigerian musical generation, there are more vibrant tunes and sounds than local content, the message is zero, and the content is only in the head of the singer. It was primarily a disarticulated economy (manipulated by a base political elite) that led the nouveau musicians into concentrating on money, in place of playing music with deep contents (music for social mobilization)

But in spite of the lack of philosophical depth in their songs, argues Barclays (2014, p.7) many Nigerian music artists get nominated for national and international music awards. Then the devious and cold political elites perceive the possibilities of electoral gains in the putative popularity of the local musical celebrities (of international repute). They consequently invite them to play at their campaign rallies. The names of the musicians attract mammoth crowds to the egregious political fetes. But the ostensibly huge gatherings are peopled by the unemployed youths again. The crowds are known also to consist mainly of sundry miscreants, pickpockets and other bewildered citizens, who had nowhere else to go on the days of such curious political carnivals. The musicians accordingly play to no one in particular on such occasions. The political gatherings therefore encounter a palpable absence of social mobilization in their tendencies. At the end of the day, these same set of assumed leaders are retained in office and the national economy remains in perpetual comatose condition.

According to Oxfam International $(2017$, p.4) the scale of economic inequality in Nigeria has reached extreme levels, and it finds expression in the daily struggles of most citizens (in the face of accumulation of obscene amounts of wealth by a small number of individuals, indeed, a small number of mindless elites). Thus, elite capture of public sector policies (and public sector resources) undermines the productivity of the most important sectors of the economy and prevents the fair distribution of the benefits of growth (Oxfam International, 2017, p.5). Nigeria's oligarchs (Nigeria's greedy elites) in the process reap 80 percent of the nation's oil profits (Kinnan et al., 2011, p.5). Then according to Ojukwu, et al (2016, p. 121), the global music scene isn't complete without the Nigerian pop music and this is the reason various foreign artistes come to sing or perform in Nigeria, with every performance targeted towards Nigerian youths. The critical question however still borders on the import of the global status of Nigerian (pop) music to social mobilization at the domestic setting.

Akombo (2014) has already alluded to the paradox of African poverty against the backdrop of a rich musical heritage. Nigeria is indeed substitutable for Africa in Akombo's thesis. In other words, why has poverty persisted in Nigeria (Africa) and music is not substantially devoted to the criticism and caricature of the contemptible power elite behind the economic quagmire? And Nigerian musicians indeed appear to have a huge followership among Nigerians, particularly among the country's teeming youth population (Adebayo, 2017, p.70). But why has this putatively massive admiration continued to record egregious shortcomings, in the regards of social mobilization? 
Jayeola (2015, p.106) describes music as an ardent social mobilizer. But in extant tendencies, the role of music as social mobilizer in Nigeria remains questionable. Barclays (2014, p.2) had also opined that apart from entertaining listeners, music should convey messages that point the way forward to the citizenry. In other words, apart from entertaining listeners, music should additionally convey messages of social mobilization.

Nigerian musicians were increasingly expected to engage more directly in acts of social mobilization. Hence, in January 2017, Mr Innocent Idibia (popularly called 2Face Idibia) and arguably one of the most decorated and most successful African musical artists of his generation, gradually commenced building a critical mass of people who would protest against the inefficiencies of the government of Nigeria (Adebayo, 2017, p.71; Augoye, 2017). The protest was scheduled for February 5, 2017. Mr Idibia shared the news of these intentions with his 1.8 million followers on Instagram (Augoye, 2017). And the Nigerian nation largely remained expectant of the auguries of the proposed Idibia-led protest, principally on account of his enormous national and international followership. But after the planned national protest had gained traction, with several public figures and civil society groups pledging to be part of the anticipated epic protest, Mr Idibia, citing "security challenges", announced a cancellation of the massively hyped march (Oyedeji, 2017).

Then the point is that "security challenges" (reason for cancelling the proposed protest) could mean anything, inclusive of the corruptive powers at the disposal of the political elite in the country, through the colossal cash they divert from the deficient political economy. The aborted protest was an opportunity lost for continuity in social mobilization in the country. It remains demonstrative of the defeats that degenerate-politics could unleash on musical activism and social mobilization in the country. Corruption is a dominant disarticulating issue in Nigerian affairs (Ojukwu \& Shopeju, 2010; Agbiboa, 2012; Ellis, 2016; Das, 2018). It supplies sleazy funds to the political economy. The national avaricious political elite then endlessly utilize such monies to reverse the course of social mobilization in the country. There are in extant tendencies such disarticulations in the hitherto positive nexus among politics, music and social mobilization in the Nigerian nation.

\section{Conclusion and Recommendation(s)}

Findings of this study indeed indicate that the relationship among politics, music and social mobilization in Nigeria is now downbeat, thereby turning the country into a strange land, where the country's musicians sing the people's song in such a bizarre location, with social mobilization as casualty. But a national music industry is an indubitable platform for positive influence(s) on the youths and others, towards the purposes of social mobilization. The inert and potential linkages between politics, music and social mobilization in Nigeria (and the African continent) must accordingly become unbridled. It is recommended for implementation by political parties in Nigeria, the establishment of music departments, in other words, the formation of musical bands, which would play at their rallies, in the manner of supporters clubs of sporting activities (particularly in the case of soccer). The likely positive effect of the addition of such bands to the Nigerian political culture is enormous. Above every other consideration, it would engender in immense dimensions, some positive linkages among politics, music and social mobilization in Nigeria.

\section{References}

[1]Abioye, L. A. (2017). Issues and themes in traditional festivals as agents of social mobilization. Cross-Cultural Communication, 13(2), 9-15.

[2]Adebanwi, W., \& Obadare, E. (2010). Introducing Nigeria at fifty: The nation in narration. Journal of Contemporary African Studies, 28(4), 379-405.

[3]Adebayo, J. O. (2017). 'Vote not Fight': Examining music's role in fostering non-violent elections in Nigeria. African Journal on Conflict Resolution, 17(1), 55-77.

[4]Adegoju, A. (2009). The musician as an activist: An example of Nigeria's Lagbaja. Itupale Online Journal of African Studies, 1 (2), 1-23. 
[5]Ademilokun, M. (2013). Discursive features of selected political song texts of the 2011 electioneering campaign rallies in South-western Nigeria. AFRREV IJAH: An

[6]International Journal of Arts and Humanities, 2(4), 262-282.

[7]Ademilokun, M., \& Olateju, M. (2016). A multimodal discourse analysis of some visual images in the political rally discourse of 2011 electioneering campaigns in Southwestern Nigeria. International Journal of Society, Culture \& Language, 4(1), 1-19.

[8]Adamolekun, W. (1989, October 23-27). Social mobilization: Tool for effective grassroots communication for national transformation. Paper presented at the Annual Conference of African Council on Education Communication (ACCE), University of Ibadan, Nigeria.

[9]Adeoye, J. O. (2013). Patriotic music: A tool for sustaining national security in Nigeria. Ondo Journal of Science and Science Education, 4(1), 9-15.

[10]Agbaje, A., \& Adejumobi, S. (2006). Do votes count? The travails of electoral politics in Nigeria. Africa Development, 31(3), 25-44.

[11] Agbiboa, D. E. (2012). Between corruption and development: The political economy of state robbery in Nigeria. Journal of Business Ethics, 108(3), 325-345.

[12] Akanni, A. A., \& Adam, A. A. (2017). Complacency, religious mediocrity and poverty among youth: Formidable threats to national security in Nigeria. AGOGO: Journal of Humanities, ), 16-23.

[13] Akeju, K. F., \& Olanipekun, D. B. (2014). Unemployment and economic growth in Nigeria. Journal of Economics and Sustainable Development, 5(4), 138-144.

[14] Akombo, D. O. (2014). Deconstructing African poverty against the backdrop of a rich musical heritage: A paradox. In T. Falola \& J. Abidogun (Eds.), Education, Creativity, and Economic Empowerment in Africa (pp. 221-231). New York: Palgrave Macmillan.

[15] Akpabot, S.E. (1986). Foundation of Nigerian traditional music: Ibadan, Nigeria: Spectrum Books.

[16] Amao, O. B., \& Okeke-Uzodike, U. F. O. (2015). Nigeria, Afro-centrism and conflict resolution: Five decades after - how far, how well? African Studies Quarterly, 15(4), 1-23.

[17]Amao, O. B., \& Maiangwa, B. (2017). Has the giant gone to sleep? Re-assessing Nigeria's response to the Liberian civil war (1990-1997) and the Boko Haram insurgency (2009-

[18]2015). African Studies, 76(1), 22-43.

[19] Amifor, J. (2015). Political advertising design in Nigeria, 1960-2007. AFRREV IJAH: An International Journal of Arts and Humanities, 4(2), 149-163.

[20] Asaju, K., Arome, S., \& Anyio, S. F. (2014). The rising rate of unemployment in Nigeria: The socio-economic and political implications. Global Business and Economics Research Journal, $3(2), 12-32$.

[21] Ashindorbe, K. (2018). Electoral violence and the challenge of democratic consolidation in Nigeria. India Quarterly, 74 (1): 92-105

[22] Augoye, J. (2017). Recession: 2Face plans to lead nationwide protest. Retrieved from https://www.premiumtimesng.com/entertainment/music/221502-recession- 2face\%E2\%80\%8Eplans-lead-nationwide-protest.html.

[23] Awopeju, A. (2011). Election rigging and the problems of electoral act in Nigeria. Afro Asian Journal of Social Sciences, 2(2), 1-17. 
[24]Babalola, S. O. (2014). Popular music as an economic tool for Nigerian youth. In T. Falola \& J. Abidogun (Eds.), Education, Creativity, and Economic Empowerment in Africa (pp. 243254). New York: Palgrave Macmillan.

[25]Bakare, A. S. (2012). Measuring the income inequality in Nigeria: the Lorenz Curve and Gini co-efficient approach. American Journal of Economics, 2(1), 47-52.

[26]Barclays, F.A. (2014, July9-12). The music artist as a social critic in Nigeria's contemporary democratic experiment: A study of selected songs of Adviser Nowamagbe. Paper presented at the African Theatre Association (AFTA) Annual International Conference, University of Ghana, Accra, Ghana.

[27] Bartlett, J., Krasodomski-Jones, N., Fisher, A., \& Jesperson, S. (2015). Social media for election communication and monitoring in Nigeria, London: Demos.

[28]Boone, C. (1998). Empirical statehood and reconfigurations of political order. In L. Villalon, \& P. Huxtable (Eds.). The African state at a critical juncture: Between disintegration and reconfiguration (pp. 129-142). Boulder, CO, USA: Lynne Rienner.

[29] Cardoso, G., Lapa, T., \& Fátima, B. (2016). People are the message? Social mobilization and social media in Brazil. International Journal of Communication, 10(2016), 3909-3930.

[30]Chang, K. O. B., \& Chen, W. (1998). Reggae routes: The story of Jamaican music. Philadelphia: Temple University Press.

[31]Das, V. (2018). Kleptocracy in Nigeria. Journal of Financial Crime, 25(1), 57-69.

[32]Deutsch, K. W. (1961). Social mobilization and political development. American Political Science Review, 55(3), 493-514.

[33]Dike, V. E., \& Dike, N. I. (2017). Youth development and conflict resolution in Nigeria: Assessment and intervention strategies. Asian Journal of Education and Training, 3(1), 30-42.

[34]Dunu, I. V., \& Uzochukwu, C. E. (2015). Social media: An effective tool for social mobilization in Nigeria. IOSR Journal of Humanities and Social Sciences, 20(4), 10-21.

[35] Duvall, R., \& Welfling, M. (1973). Social mobilization, political institutionalization, and conflict in Black Africa: A simple dynamic model. Journal of Conflict Resolution, 17(4), 673-702.

[36]Ellis, S. (2016). This present darkness: A history of Nigerian organized crime. London: C. Hurst.

[37]Emecheta, K. O. O. (2016). Power to the people: An inverse role in Nigeria's politics and governance. International Journal of Area Studies, 11(2), 83-102.

[38]Englebert, P. (2002). Patterns and theories of traditional resurgence in tropical Africa. Mondes en développement, 2(-), 51-64.

[39]Evans, E. (2007). The power of political mobilization. Small Wars Journal, 7(1): 40-55

[40]Fayoyin, A., \& Nieuwoudt, S. (2017). The power of song in the struggle for health and development outcomes in Africa: Lessons for social and behaviour change programmes. Journal of Intellectual Property Rights, 5(2), 1-6.

[41] Gyimah-Brempong, K., \& Kimenyi, M. S. (2013). Youth Policy and the future of African development. African Growth Initiative Working Paper, No. 9. Washington, DC: The Brookings Institution

[42]Ijeh, P. N. (2012). Voters' perception of cultural elements in political advertising for the April 2011 general elections in Nigeria. Acta Universitatis Danubius. Communicatio, 6(2). 15-30

[43]Ikpe, U. B. (2015). Rethinking electoral violence and democratic consolidation in Nigeria. Journal of Asian and African Studies, 50(1), 96-108. 
[44]Itiri, N.U. (2015). From entertainment to politics: Nigerian celebrities and the 2015 general elections, VUNA Journal of History and International Relations, 2(2).249-257.

[45] Jayeola, F. (2015). Indigenous music in Nigeria: Its role towards national development. FUNAI Journal of Humanities and Social Sciences, 1 (2): 102-109.

[46] Kashim, I. B., Ogunduyile, S. R., \& Adelabu, O. S. (2011). Culturally inspired design education: A Nigerian case study. In D. A. Coelho (Ed.): Industrial Design-New Frontiers. Retrieved from https://www.intechopen.com/books/industrial-design-new-frontiers.

[47] Kinnan, C. J., Gordon, D. B., DeLong, M. D., Jaquish, D. W., \& McAllum, R. S. (2011). Failed state 2030, Nigeria: A case study. Retrieved from http://www.airuniversity.af.mil/CSAT/Display/Article/1125622/occasional-papers/.

[48] Mengisteab, K. (2006). Relevance of African traditional institutions of governance: A concept paper submitted to the Development Policy Management Division, the United Nations Economic Commission for Africa (UNECA), Addis Ababa: Ethiopia.

[49] MINDS, (2016). Youth participation in elections in Africa: An eight-country study. Hyde Park, South Africa: Author.

[50] Mijuskovic, B. (1992). Organic communities, atomistic societies, and loneliness. The Journal of Sociology \& Social Welfare, 19(2): 147-165.

[51] Musa, A., Abdullahi, D., \& Baba, Y. T. (2017). Youth unemployment and violent mobilization in Kebbi State. International Journal of Social and Administrative Sciences, 2(1), 1-7.

[52]Nsude, I., \& Isika, G., U. (2016). Traditional structures and media for development and mass mobilization in Nigeria, IOSR Journal of Humanities and Social Sciences, 21(11), 71-77.

[53] Nwosu, O. (2017). The ballot and the bard. Ikenga International Journal of African Studies, 17(1),78-87.

[54] Ofulue, C. I. (2016). Language of politics and identity: A sociolinguistic study of linguistic practices in Nigerian political campaign advertising on social media. Ihafa: A Journal of African Studies, 8(2), 229-261.

[55] Ogbeide, E. N. O., \& Agu, D. O. (2015). Poverty and income inequality in Nigeria: Any causality? Asian Economic and Financial Review, 5(3), 439-452.

[56] Ojukwu, E., Obielozie, E., \& Esimone, C. (2016). Nigerian values and contemporary popular music: A new look. OGIRISI: A New Journal of African Studies, 12(-), 114-129.

[57] Ojukwu, C. C., \& Shopeju, J. O. (2010). Elite corruption and the culture of primitive accumulation in 21 st century Nigeria. International Journal of Peace and Development Studies, 1(2), 15-24.

[58] Okuyade, O. (2011). African China, Nigerian popular music, national development and the search for musical idiom. Muziki, 8(2), 50-59.

[59] Olatunji, R. W. (2013). Uses of semiotics in periods of hostilities, armed conflicts and peace building among the Yoruba, South-West Nigeria. AFRREV IJAH: An International Journal of Arts and Humanities, 2(4), 247-261.

[60] Omojola, O. (1994). Education in Nigeria: Historical trends, Ilorin Journal of Education, 14(-), $1-5$.

[61] Onah, F.O. (2009). Electoral process and democracy in Nigeria, (1999-2007): An appraisal ESUT Journal of Administration, 2 (1):1-19.

[62] Onikoyi, A. (2014). "Problem with the entertainment industry." Potpourri. Sunday Vanguard. 20 April. 18. 
[63] Osiebe, G. (2015). The opportunism of political music culture in democratic Nigeria, Journal of African Cultural Studies, 28(1), 13-27

[64] Oxfam International (2017): Inequality in Nigeria: Exploring the drivers. Oxford, United Kingdom. Author

[65]Oyedeji, O. (2017). Tuface backs off, cancels anti-govt protest. Retrieved from https://www.premiumtimesng.com/news/headlines/222566-tuface-backs-off-cancels-anti.. protest.html.

[66] Oyelola, O. T., Igwe, N. C., Ajiboshin, I. O., \& Peluola, S. B. (2014). Entrepreneurship education: Solution to youth unemployment in Nigeria. Journal of Poverty, Investment and Development, 5, 149-157.

[67] Reddy, T. (2010). ANC decline, social mobilization and political society: Understanding South Africa's evolving political culture. Politikon, 37(2-3), 185-206.

[68] Salaudeen, K. A., \& Adebiyi, R. A. (2017). Political persuasion through cultural appeal: An analysis of radio commercials of the 2015 election in Oyo State, South-West, Nigeria. The Journal of Pan African Studies, 10(5), 30-42.

[69] Sam, S. (2015). Institutionalizing social mobilization as a social change process. Retrieved from http://www.waccglobal.org/articles/institutionalising-social-mobilisation-as-a-social change-process

[70] Sen, Y. (2010). Challenges and prospects of Nigeria's development at 50. Retrieved from https://carleton.ca/africanstudies/wp-content/uploads/yima-sen-lecture.pdf.

[71] Smith, D. J. (2010). A culture of corruption: Everyday deception and popular discontent in Nigeria. Princeton, N.J: Princeton University Press.

[72] Sobowale, I. (2013, May 17). Communication, politicians and true democracy. Covenant University, Ota, Nigeria. 35th Public Lecture.

[73] Titus, O. S., \& Bello, O. A. (2012). Musical forms in songs for political mobilization during 2011 general elections in Nigeria. International Journal of Humanities and Social Science, 2(13), 166-173.

[74] Tufte, T. (2013). Towards a renaissance in communication for social change: Redefining the discipline and practice in the post-'Arab Spring' era. In T. Tufte, N. Wildermuth, A. HansenSkovmoes \& W. Mitullah (Eds.), Speaking up and talking back? Media,

empowerment and civic engagement of African youth. Goteborg, Sweden: Nordicom.

[75] Tule, M. K., Oduh, M. O., Chiemeke, C. C., \& Ndukwe, O. C. (2018). An assessment of the severity of unemployment in Nigeria: Evidence from fractional integration. Journal of African Business, 19(1), 39-61.

[76] Umukoro, N. (2014). Democracy and inequality in Nigeria. Journal of Developing Societies, 30(1), 1-24.

[77]Unicef (2017): Community engagement: Social mobilization. Retrieved from https://www.unicef.org/cbsc/index_65175.html.

[78] Wader, M. M., Jumare, H., \& Imam, M. (2016). Music, musicians and politics: The case study of the Nigerian 2015 general elections. International Journal of Innovative Research and Advanced Studies, 3(7), 66-71.

[79] Yelwa, M., David, O. O., \& Awe, E. O. (2015). Analysis of the relationship between inflation, unemployment and economic growth in Nigeria: 1987-2012. Applied Economics and Finance, 2(3), 102-109. 